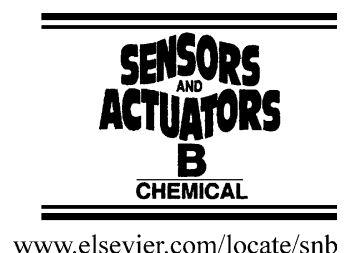

www.elsevier.com/locate/snb

\title{
Amperometric detection of hydrogen peroxide at a Prussian Blue-modified FTO electrode
}

\author{
Kuei-Sheng Tseng ${ }^{\mathrm{a}}$, Lin-Chi Chen ${ }^{\mathrm{a}}$, Kuo-Chuan $\mathrm{Ho}^{\mathrm{a}, \mathrm{b}, *}$ \\ a Department of Chemical Engineering, National Taiwan University, Taipei 10617, Taiwan \\ ${ }^{\mathrm{b}}$ Institute of Polymer Science and Engineering, National Taiwan University, Taipei 10617, Taiwan
}

Received 13 July 2004; received in revised form 30 November 2004; accepted 1 December 2004

Available online 12 January 2005

\begin{abstract}
This research focuses on the use of a Prussian Blue (PB)-modified optically transparent electrode for sensing hydrogen peroxide $\left(\mathrm{H}_{2} \mathrm{O}_{2}\right)$. The PB thin films were deposited galvanostatically onto F-doped tin oxide (FTO) glass substrates. Then a reliable and reproducible detection was achieved by exerting a constant bias of $-0.2 \mathrm{~V}$ (versus $\mathrm{Ag} / \mathrm{AgCl} /$ saturated $\mathrm{KCl}$ ) at the PB-modified FTO electrode immersed in an $\mathrm{H}_{2} \mathrm{O}_{2}$ solution containing $0.1 \mathrm{M} \mathrm{KCl}, \mathrm{pH} 2$. The dynamic range of detection was found to lie between $50 \mu \mathrm{M}$ and $50 \mathrm{mM}$, and the sensitivity was ca. $58.1 \mathrm{~mA} / \mathrm{cm}^{2} \mathrm{M}$. But it was also observed that the dissolved oxygen interfered the $\mathrm{H}_{2} \mathrm{O}_{2}$ sensing. Better sensing results could be obtained if the solution was pre-purged with $\mathrm{N}_{2}$. To sum up, this study possesses the potential to eliminate the use of costly platinum or glassy carbon in a $\mathrm{PB}$-based $\mathrm{H}_{2} \mathrm{O}_{2}$ sensor and may provide the basis for optical sensing.
\end{abstract}

(C) 2004 Elsevier B.V. All rights reserved.

Keywords: FTO; Hydrogen peroxide; Modified electrode; Prussian Blue; $\mathrm{H}_{2} \mathrm{O}_{2}$ sensor

\section{Introduction}

Detection of hydrogen peroxide $\left(\mathrm{H}_{2} \mathrm{O}_{2}\right)$ has been an important topic for sensor research for decades. The relevant techniques have been applied to industrial, environmental, clinical, and food analyses [1-3]. Among them, amperometric detection is one of the promising approaches to achieve accurate, specific, economical, and rapid $\mathrm{H}_{2} \mathrm{O}_{2}$ monitoring. To date, a multitude of commercial electrochemical biosensors are based on oxidase-modified electrodes, which react with bio-substrates and yield $\mathrm{H}_{2} \mathrm{O}_{2}$, and thus sensing $\mathrm{H}_{2} \mathrm{O}_{2}$ induced currents in practice. An elaborate review about the fundamentals and applications of peroxidase-modified electrodes could be found in the paper by Ruzgas et al. [4]. In the earlier days, amperometric detection of $\mathrm{H}_{2} \mathrm{O}_{2}$ was usually performed at either platinum $(\mathrm{Pt})$ or platinized surface

\footnotetext{
* Corresponding author. Tel.: +88622366 0739; fax: +886223623040. E-mail address: kcho@ntu.edu.tw (K.-C. Ho).
}

$[5,6]$. Yet, the trend has been employing chemically modified electrodes to detect $\mathrm{H}_{2} \mathrm{O}_{2}$ since two decades ago.

Cox and Jaworski reported that a glassy carbon (GC) electrode modified by a thin film composed of palladium and iridium could catalyze the reduction of $\mathrm{H}_{2} \mathrm{O}_{2}$ [7]. In contrast to the reduction of $\mathrm{H}_{2} \mathrm{O}_{2}$, Taha and Wang modified a GC electrode by a thin film of oxymanganese species, which catalyzed the oxidation of $\mathrm{H}_{2} \mathrm{O}_{2}$ [8]. Also, Khoo et al. monitored a fermentation process by detecting the oxidation of $\mathrm{H}_{2} \mathrm{O}_{2}$ at a GC electrode modified by an oxycobalt film [9]. Besides the above-mentioned modified layers, transition metal hexacyanoferrates (MHCF) as well as Prussian Blue (PB) analogs have been considered as another class of interesting materials for $\mathrm{H}_{2} \mathrm{O}_{2}$ electrocatalysis for years. Table 1 summarizes a partial list of literature reporting the performances of amperometric $\mathrm{H}_{2} \mathrm{O}_{2}$ detection based on $\mathrm{PB}$ and its analogs [10-17].

As far as the electrochemistry of PB is concerned, it is known that $\mathrm{PB}$ features multiple redox states. With a high formal potential of ca. $0.87 \mathrm{~V}$ versus SCE, PB can be oxidized to yield Berlin green (BG) reversibly when using a 
Table 1

A partial list of literature reporting amperometric $\mathrm{H}_{2} \mathrm{O}_{2}$ detection based on Prussian Blue and its analogs

\begin{tabular}{|c|c|c|c|c|}
\hline Electrode configuration $^{\mathrm{a}}$ & Operating potential & Sensitivity $\left(\mathrm{mA} / \mathrm{cm}^{2} \mathrm{M}\right)$ & Dynamic range (M) & References \\
\hline $\mathrm{PB} / \mathrm{FTO}^{\mathrm{b}}$ & $-0.20 \mathrm{~V}$ vs. $\mathrm{Ag} / \mathrm{AgCl}$ & 58.1 & $5 \times 10^{-5}$ to $5 \times 10^{-2}$ & This work \\
\hline $\mathrm{PB} / \mathrm{GC}^{\mathrm{c}}$ & $0.18 \mathrm{~V}$ vs. $\mathrm{Ag} / \mathrm{AgCl}$ & 1000 & $1 \times 10^{-6}$ to $1 \times 10^{-2}$ & {$[10]$} \\
\hline $\mathrm{PB} / \mathrm{GC}^{\mathrm{d}}$ & $-0.05 \mathrm{~V}$ vs. $\mathrm{Ag} / \mathrm{AgCl}$ & 600 & $1 \times 10^{-7}$ to $1 \times 10^{-4}$ & [11] \\
\hline $\mathrm{CrHCF} / \mathrm{GC}^{\mathrm{c}}$ & $0.00 \mathrm{~V}$ vs. $\mathrm{Ag} / \mathrm{AgCl}$ & 1152 & $3 \times 10^{-8}$ to $1.3 \times 10^{-3}$ & {$[12]$} \\
\hline $\mathrm{PB} / \mathrm{SPE}^{\mathrm{b}}$ & $0.00 \mathrm{~V}$ vs. $\mathrm{Ag} / \mathrm{AgCl}$ & 137 & $4 \times 10^{-7}$ to $1 \times 10^{-4}$ & {$[13]$} \\
\hline $\mathrm{PB} /$ graphite $^{\mathrm{e}}$ & $0.45 \mathrm{~V}$ vs. SCE & 0.7 & NA & [14] \\
\hline $\mathrm{PB} / \mathrm{CPE}^{\mathrm{e}}$ & $-0.20 \mathrm{~V}$ vs. $\mathrm{Ag} / \mathrm{AgCl}$ & 0.9 & NA & [15] \\
\hline $\mathrm{PB} / \mathrm{GC}^{\mathrm{d}}$ & $-0.05 \mathrm{~V}$ vs. $\mathrm{Ag} / \mathrm{AgCl}$ & 300 & NA & {$[16]$} \\
\hline Nano-PB/GC & $0.05 \mathrm{~V}$ vs. $\mathrm{Ag} / \mathrm{AgCl}$ & 60 & $1 \times 10^{-8}$ to $1 \times 10^{-2}$ & {$[17]$} \\
\hline
\end{tabular}

SPE: screen printing electrode; CPE: carbon paste electrode.

a Different detection systems were compared.

b Static electrochemical cell.

c Rotating disk electrode (RDE) system.

d Flow-injection system.

e Continuously stirred electrochemical cell.

$\mathrm{K}^{+}$-containing electrolyte $[18,19]$. On the other hand, PB can be reversibly reduced to Prussian white (PW or Everitt's salt, ES). The formal potential of $\mathrm{PB} / \mathrm{PW}$ redox system is ca. $0.20 \mathrm{~V}$ versus SCE $[18,19]$. Among the redox states of $\mathrm{PB}$, it is the PW state to reduce $\mathrm{H}_{2} \mathrm{O}_{2}$ and to act as an electron-transfer mediator between the electrode and $\mathrm{H}_{2} \mathrm{O}_{2}$, which can be initially present in solution or be produced from an enzyme-catalyzed reaction. In the middle of 1980s, Itaya et al. first discovered that an electrodeposited PB thin film is an excellent catalyst for both $\mathrm{O}_{2}$ and $\mathrm{H}_{2} \mathrm{O}_{2}$ electrochemical reductions [20]. Recently, Karyakin et al. further demonstrated that the catalytic ability of $\mathrm{PB}$ is even better than that of bare platinum [10]. Also, a lot of $\mathrm{H}_{2} \mathrm{O}_{2}$ sensors based on a PB-modified GC electrode [10,11,16,17,20,21] or a PB-modified Pt electrode [22,23] have been successfully investigated. In addition, other metal hexacyanoferrates have been investigated as electrocatalysts for $\mathrm{H}_{2} \mathrm{O}_{2}$. For example, Lin et al. modified a glassy carbon electrode by cobalt(II) hexacyanoferrate and chromium(III) hexacyanoferrate, and fabricated amperometric $\mathrm{H}_{2} \mathrm{O}_{2}$ sensors, accordingly [12].

The fact mentioned in the above paragraph convinces us that a PB-based $\mathrm{H}_{2} \mathrm{O}_{2}$ sensor may be commercially viable. Nonetheless, the cost of a Pt or GC electrode is on the hard side. Therefore, the aim of this work is to develop a lowcost, easy-operating, and high-sensitive $\mathrm{H}_{2} \mathrm{O}_{2}$ sensing process based on a PB-modified optically transparent electrode (OTE), in which the F-doped tin oxide (FTO) glass serves as the OTE. Although, there are many researchers reporting $\mathrm{H}_{2} \mathrm{O}_{2}$ sensing based on PB-modified electrodes, there is no reported literature, to our best knowledge, using a PBmodified OTE to detect $\mathrm{H}_{2} \mathrm{O}_{2}$. Moreover, FTO glasses are superior to ordinary glassy carbon or platinum electrode from the cost consideration. Besides, FTO glasses can allow optical sensing [24]. In this paper, a reproducible and reliable $\mathrm{H}_{2} \mathrm{O}_{2}$ sensing process at the PB-modified FTO electrode (denoted as $\mathrm{PB} / \mathrm{FTO}$ ) using the amperometric method will be presented. $\mathrm{PB} / \mathrm{FTO}$ electrode stability, $\mathrm{H}_{2} \mathrm{O}_{2}$ catalytic mechanisms, detection limits and reproducibility of $\mathrm{H}_{2} \mathrm{O}_{2}$ sens- ing, and oxygen interference will also be discussed thoroughly.

\section{Experimental}

\subsection{Materials and apparatus}

The main chemicals used in this work were $\mathrm{FeCl}_{3}$, $\mathrm{K}_{3} \mathrm{Fe}(\mathrm{CN})_{6}, \mathrm{KCl}, \mathrm{HCl}$, and high-purity $\mathrm{N}_{2}$ gas $(99.9 \%)$. All of them were ACS reagent grade and not further purified. Deionized water (DIW) was used throughout. F-doped $\mathrm{SnO}_{2}$ (FTO) coated glass substrates $\left(R_{\mathrm{sh}}=20 \Omega /\right.$ sq. and $2 \mathrm{~mm}$ in thickness) were obtained from a local supplier (Sinonar Corporation, Hsinchu, Taiwan). Before using, FTO glass substrates were washed ultrasonically with $0.1 \mathrm{M} \mathrm{HCl}$ for $5 \mathrm{~min}$ and with DIW for another 5 min. After an extra DIW rinse, the substrates were dried in air. When preparing an FTO electrode, a piece of copper tape (3M Company), serving as the bus bar, was applied to the FTO-coated surface of a glass substrate, and then a insulating tape was applied to the same surface to define an electrode area of $3.0 \mathrm{~cm} \times 1.0 \mathrm{~cm}$.

All of the electrochemical experiments were performed in a three-electrode cell $(V=50 \mathrm{~mL})$ without or with a magnetic stirring. A home-made $\mathrm{Ag} / \mathrm{AgCl} /$ saturated $\mathrm{KCl}$ reference electrode and a Pt planar auxiliary electrode were used. Electrode potentials or currents were controlled using a potentiostat/galvanostat (Autolab, model PGSTAT30), which also collected electrochemical responses. All of the experiments were done at room temperature.

\subsection{Electrodeposition of the PB thin films on the FTO glass substrates}

Prussian Blue thin films were electrodeposited galvanostatically onto the FTO glass substrates: a cathodic bias with a constant current density of $20 \mu \mathrm{A} / \mathrm{cm}^{2}$ was exerted to the FTO substrate immersed in the aqueous solution of $10 \mathrm{mM} \mathrm{K}_{3} \mathrm{Fe}(\mathrm{CN})_{6}, 10 \mathrm{mM} \mathrm{FeCl}_{3}$, and $10 \mathrm{mM} \mathrm{HCl}$ for $300 \mathrm{~s}$. 
An insoluble form of PB was thus electrodeposited by the chosen method $[19,20]$. The as-prepared PB-modified FTO (PB/FTO) electrodes films were washed with DIW and then were dried in air for at least $24 \mathrm{~h}$ prior to use. For quality controls, the charge capacities of PB thin films were measured based on chronoamperometry, in which a potential step, switched from +0.70 to $-0.20 \mathrm{~V}$ (versus $\mathrm{Ag} / \mathrm{AgCl} /$ saturated $\mathrm{KCl}$ ), was applied to a PB/FTO electrode in $0.1 \mathrm{M} \mathrm{KCl}$ aqueous solution $(\mathrm{pH} \mathrm{2}$, adjusted with $\mathrm{HCl})$ for $30 \mathrm{~s}$. Also, the $\mathrm{PB} / \mathrm{FTO}$ electrode was characterized using cyclic voltammetry $(\mathrm{CV})$ in the same electrolyte at a scan rate of $5 \mathrm{mV} / \mathrm{s}$.

\subsection{Linear sweep voltammetry for the PB/FTO electrode in the presence of $\mathrm{H}_{2} \mathrm{O}_{2}$}

To search for an ideal electrocatalytic condition for $\mathrm{H}_{2} \mathrm{O}_{2}$, linear sweep voltammetry (LSV) was performed to PB/FTO electrodes in contact with the following aqueous solutions: (1) $10 \mathrm{mM} \mathrm{H}_{2} \mathrm{O}_{2}, \mathrm{pH} \mathrm{5}$; (2) $10 \mathrm{mM} \mathrm{H}_{2} \mathrm{O}_{2}, \mathrm{pH} \mathrm{2}$; and (3) $10 \mathrm{mM} \mathrm{H} \mathrm{H}_{2} \mathrm{O}_{2}+0.1 \mathrm{M} \mathrm{KCl}, \mathrm{pH}$ 2. The solution $\mathrm{pH}$ values were adjusted with $\mathrm{HCl}$. For each run, the electrode potential was scanned linearly from 0.75 to $-0.50 \mathrm{~V}$ (vs. $\mathrm{Ag} / \mathrm{AgCl} /$ saturated $\mathrm{KCl}$ ) at a scan rate of $30 \mathrm{mV} / \mathrm{s}$.

\subsection{Sampled-current voltammetry for $\mathrm{H}_{2} \mathrm{O}_{2}$ catalytic reduction}

By the potential step method, sampled-current voltammograms (steady-state currents versus electrode potentials) for $\mathrm{H}_{2} \mathrm{O}_{2}$ reduction at the $\mathrm{PB} / \mathrm{FTO}$ electrode were determined. Electrolytic solution composed of $10 \mathrm{mM} \mathrm{H}_{2} \mathrm{O}_{2}$ and $0.1 \mathrm{M} \mathrm{KCl}(\mathrm{pH} 2)$ was either stationary or stirred during the measurements. Before stepping to each desired potential for steady-state current measurement (sampling time $=100 \mathrm{~s}$ ), the PB/FTO electrode was pre-equilibrated at $0.70 \mathrm{~V}$ (versus $\mathrm{Ag} / \mathrm{AgCl} /$ saturated $\mathrm{KCl}$ ) for $30 \mathrm{~s}$. By judging from the sampled-current voltammogram obtained in the stationary electrolyte, the $\mathrm{H}_{2} \mathrm{O}_{2}$ sensing potential was determined to be $-0.20 \mathrm{~V}$ (versus $\mathrm{Ag} / \mathrm{AgCl} /$ saturated $\mathrm{KCl}$ ).

\subsection{Amperometric detection of $\mathrm{H}_{2} \mathrm{O}_{2}$ at the PB/FTO electrode}

The amperometric detection was carried out by applying $-0.20 \mathrm{~V}$ (versus $\mathrm{Ag} / \mathrm{AgCl} /$ saturated $\mathrm{KCl}$ ) at a PB/FTO electrode in contact with non-stirred solutions of different $\mathrm{H}_{2} \mathrm{O}_{2}$ concentrations. All of the $\mathrm{H}_{2} \mathrm{O}_{2}$ solutions contained $0.1 \mathrm{M} \mathrm{KCl}$ and a trace amount of $\mathrm{HCl}$ (to adjust $\mathrm{pH}$ to 2). The electrode was pre-equilibrated at $0.70 \mathrm{~V}$ for $30 \mathrm{~s}$ before each run of the detection, and the steady current readings at $-0.20 \mathrm{~V}$ were acquired after $100 \mathrm{~s}$. To investigate the effect of dissolved oxygen on the detection, the amperometric experiments without (as described above) and with $5 \mathrm{~min}$ high-purity $\mathrm{N}_{2}(99.9 \%)$ purging were compared.

\section{Results and discussions}

\subsection{Electrochemical characteristics of the PB-modified FTO electrode}

Fig. 1 shows the cyclic voltammogram of a PB/FTO electrode cycled in an electrolyte of $0.1 \mathrm{M} \mathrm{KCl}(\mathrm{pH} 2)$ and reveals the existence of two redox systems-PB/PW and BG/PB. It can be found that their redox potentials are in the vicinity of 0.20 and $0.90 \mathrm{~V}$ (versus $\mathrm{Ag} / \mathrm{AgCl} /$ saturated $\mathrm{KCl}$ ), respectively. This is consistent with the $\mathrm{CV}$ of a PB-modified GC electrode reported by Itaya et al. [20]. In the present study, we focused on the PB/PW redox system because of the high reducing ability of PW. In Fig. 1, a reduction current of ca. $-70 \mu \mathrm{A}$ is present when the PB electrode is biased to the PW state, and this current is presumably produced by the reduction of dissolved oxygen catalyzed by PW [20]. To be sure, it is the PW to have the capability for reducing $\mathrm{H}_{2} \mathrm{O}_{2}$ and to act as an electron-transfer mediator. The $\mathrm{PB} / \mathrm{PW}$ redox process in the presence of $\mathrm{K}^{+}$ions can be expressed as follows [20]:

$\mathrm{Fe}_{4}{ }^{\mathrm{III}}\left\lfloor\mathrm{Fe}^{\mathrm{II}}(\mathrm{CN})_{6}\right\rfloor_{3}+4 \mathrm{~K}^{+}+4 \mathrm{e}^{-} \leftrightarrow \mathrm{K}_{4} \mathrm{Fe}_{4}{ }^{\mathrm{II}}\left\lfloor\mathrm{Fe}^{\mathrm{II}}(\mathrm{CN})_{6}\right\rfloor_{3}$

where $\mathrm{Fe}_{4}\left[\mathrm{Fe}(\mathrm{CN})_{6}\right]_{3}$ and $\mathrm{K}_{4} \mathrm{Fe}_{4}\left[\mathrm{Fe}(\mathrm{CN})_{6}\right]_{3}$ are $\mathrm{PB}$ and $\mathrm{PW}$, respectively. Since $\mathrm{PB}$ has been known as a zeolite ana$\log$ with channel diameters of ca. $3.2 \AA$, hydrated $\mathrm{K}^{+}$ions are small enough to reversibly insert into and extract from the $\mathrm{PB}$ lattice and to result in very high $\mathrm{PB} / \mathrm{PW}$ redox reversibility [25]. Therefore, we chose $\mathrm{K}^{+}$ions for maintaining the electrode stability during the $\mathrm{H}_{2} \mathrm{O}_{2}$ detection. In addition to the electrochemical reversibility, high reproducibility of PB electrodeposition was confirmed. All of the electrodeposited PB films were tested by potential step experiments in the presence of $0.1 \mathrm{M} \mathrm{KCl}, \mathrm{pH} 2$ prior to use for quality control (see Section 2.2). We found that the passed charges of PB films (electrode area $=3.0 \mathrm{~cm} \times 1.0 \mathrm{~cm}$ ) were within 29.0 and $32.9 \mathrm{mC}$, and the coefficient of variation was

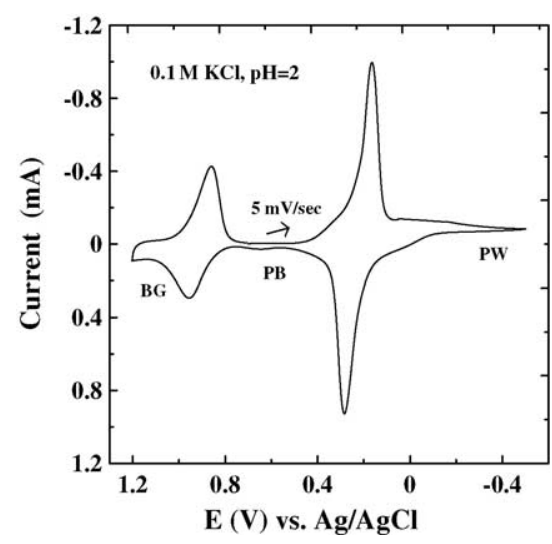

Fig. 1. Cyclic voltammogram of a PB/FTO electrode in $0.1 \mathrm{M} \mathrm{KCl}, \mathrm{pH} 2$. Scan rate $=5 \mathrm{mV} / \mathrm{s}$. 
ca. 3.96\% $(N=30)$. This means the electrode-to-electrode variation could be neglected when performing the $\mathrm{H}_{2} \mathrm{O}_{2}$ sensing.

\subsection{Determination of the $\mathrm{H}_{2} \mathrm{O}_{2}$ sensing conditions at the PB/FTO electrode}

To achieve reliable $\mathrm{H}_{2} \mathrm{O}_{2}$ detection at the PB/FTO electrode, the effects of supporting electrolytes and stirring on the electrocatalytic reaction were investigated. Fig. 2 compares cathodic linear sweep voltammograms (LSVs) of the $\mathrm{PB} / \mathrm{FTO}$ electrodes immersed in the following three aqueous solutions: (1) $10 \mathrm{mM} \mathrm{H}_{2} \mathrm{O}_{2}$, pH 5; (2) $10 \mathrm{mM} \mathrm{H}_{2} \mathrm{O}_{2}$, $\mathrm{pH} \mathrm{2;} \mathrm{(3)} 10 \mathrm{mM} \mathrm{H}_{2} \mathrm{O}_{2}, 0.1 \mathrm{M} \mathrm{KCl}, \mathrm{pH} 2$. (For solutions (2) and (3), the $\mathrm{pH}$ values were adjusted using $\mathrm{HCl}$.) It can be seen that solution (3) gives a higher reductive response than solution (2) does, whereas solution (1) has no significant signal. It is noticed that only solution (3) results in an observable cathodic peak in response to the PB-to-PW conversion, which is necessary for the $\mathrm{H}_{2} \mathrm{O}_{2}$ electrocatalysis. When the electrode potential was biased negatively beyond $-0.2 \mathrm{~V}$, the $\mathrm{PW}$-driven $\mathrm{H}_{2} \mathrm{O}_{2}$ reduction took place in solution (3), giving a net catalytic current of $\mathrm{H}_{2} \mathrm{O}_{2}$ reduction; whereas $\mathrm{PB}$ was still under conversion to $\mathrm{PW}$ in solution (2). Accordingly, in the potential region between -0.2 and $-0.4 \mathrm{~V}$, the $\mathrm{H}_{2} \mathrm{O}_{2}$ electrocatalytic current was observed in solution (3), but the PB reduction current was detected in solution (2). This explains why the current in solution (3) was smaller than that in solution (2) in the abovementioned potential region. Moreover, the addition of $0.1 \mathrm{M}$ $\mathrm{KCl}$ effectively lowers the overpotential required for the PB-mediated $\mathrm{H}_{2} \mathrm{O}_{2}$ reduction. The results can be explained by Eq. (1) and the following formula reported in literature [20]:

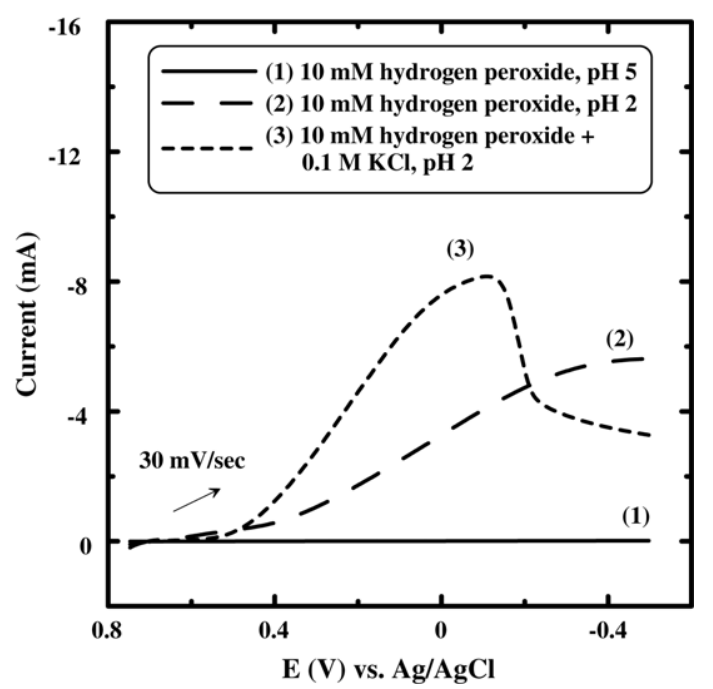

Fig. 2. Linear sweep voltammograms of $\mathrm{PB} / \mathrm{FTO}$ electrodes in: (1) $10 \mathrm{mM}$ $\mathrm{H}_{2} \mathrm{O}_{2}, \mathrm{pH} \mathrm{5}$; (2) $10 \mathrm{mM} \mathrm{H}_{2} \mathrm{O}_{2}, \mathrm{pH} \mathrm{2}$; and (3) $10 \mathrm{mM} \mathrm{H}_{2} \mathrm{O}_{2}, 0.1 \mathrm{M} \mathrm{KCl}, \mathrm{pH}$ 2. Scan rate $=30 \mathrm{mV} / \mathrm{s}$.

$$
\begin{gathered}
\mathrm{K}_{4} \mathrm{Fe}_{4}{ }^{\mathrm{II}}\left\lfloor\mathrm{Fe}^{\mathrm{II}}(\mathrm{CN})_{6}\right\rfloor_{3}+2 \mathrm{H}_{2} \mathrm{O}_{2}+4 \mathrm{H}^{+} \\
\rightarrow \mathrm{Fe}_{4}{ }^{\mathrm{II}}\left\lfloor\mathrm{Fe}^{\mathrm{II}}(\mathrm{CN})_{6}\right\rfloor_{3}+4 \mathrm{H}_{2} \mathrm{O}+4 \mathrm{~K}^{+}
\end{gathered}
$$

It can be seen in the above formula that protons act as a reactant and participate in the $\mathrm{PW}$-driven $\mathrm{H}_{2} \mathrm{O}_{2}$ reduction. In addition, Eq. (1) elucidates that the existence of $\mathrm{K}^{+}$ions can facilitate the PB-to-PW conversion. Since both the acidity and $\mathrm{K}^{+}$ions play significant roles, $\mathrm{H}_{2} \mathrm{O}_{2}$ solutions were added with $0.1 \mathrm{M} \mathrm{KCl}$ and a trace amount of $\mathrm{HCl}$ (for adjusting $\mathrm{pH}$ to 2 ) prior to analyses.

Fig. 3 compares the sampled-current voltammograms (steady-state currents versus electrode potentials) of the $\mathrm{PB} / \mathrm{FTO}$ electrodes immersed in the stationary and stirred $\mathrm{H}_{2} \mathrm{O}_{2}$ solutions ( $\left.10 \mathrm{mM} \mathrm{H}_{2} \mathrm{O}_{2}, 0.1 \mathrm{M} \mathrm{KCl}, \mathrm{pH} 2\right)$. It can be seen that stirring results in several-fold higher current response by increasing convective mass transfer of $\mathrm{H}_{2} \mathrm{O}_{2}$ from bulk solution to electrode surface. On the other hand, stirring does not yield a limiting current, which is crucial for a reliable amperometric $\mathrm{H}_{2} \mathrm{O}_{2}$ sensing, and may involve more dissolved oxygen to interfere $\mathrm{H}_{2} \mathrm{O}_{2}$ sensing (see Section 3.5). However, for the stationary case, a limiting current is achieved when the PB/FTO electrode is biased to ca. $-0.20 \mathrm{~V}$ versus $\mathrm{Ag} / \mathrm{AgCl} /$ saturated $\mathrm{KCl}$. The limiting current observed in the stationary condition implies that it was the $\mathrm{PB}$ thin film, not the $\mathrm{H}_{2} \mathrm{O}_{2}$, that plays the role of the limiting reagent in the present system. The Nernstian current-potential behavior can thus reflect the PB/PW redox characteristics. According to the above considerations, we decided to use a stationary environment to sense $\mathrm{H}_{2} \mathrm{O}_{2}$ by compromising sensitivity in exchange for reliability. And the sensing potential was thus set to $-0.20 \mathrm{~V}$ versus $\mathrm{Ag} / \mathrm{AgCl} /$ saturated $\mathrm{KCl}$. The sensing results will be given and discussed in Section 3.4 .

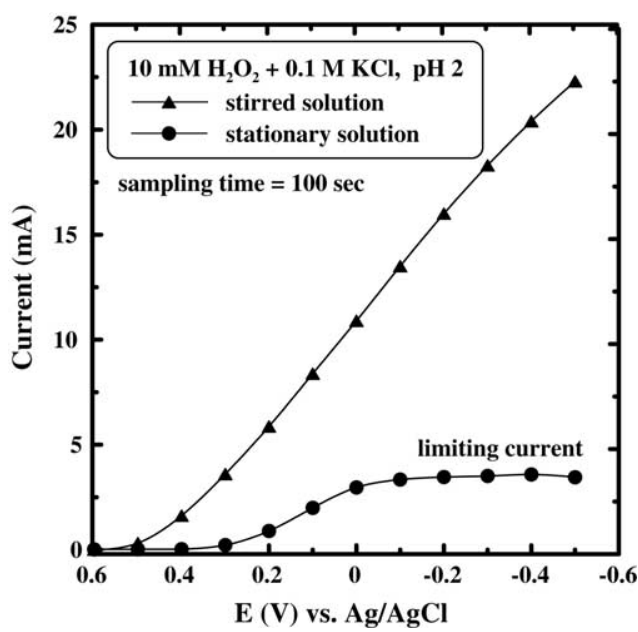

Fig. 3. Sampled-current voltammograms (steady-state currents vs. electrode potentials) of the $\mathrm{PB} / \mathrm{FTO}$ electrodes immersed in the stationary and stirred $\mathrm{H}_{2} \mathrm{O}_{2}$ solutions $\left(10 \mathrm{mM} \mathrm{H} \mathrm{O}_{2}, 0.1 \mathrm{M} \mathrm{KCl}, \mathrm{pH} 2\right)$. Sampling time $=100 \mathrm{~s}$. Before each run, the $\mathrm{PB} / \mathrm{FTO}$ electrode was re-equilibrated at $0.70 \mathrm{~V}$ (vs. $\mathrm{Ag} / \mathrm{AgCl} /$ saturated $\mathrm{KCl}$ ) for $30 \mathrm{~s}$. 


\subsection{Electrode kinetics of the $\mathrm{PB}$-catalyzed $\mathrm{H}_{2} \mathrm{O}_{2}$ reduction}

By combining Eqs. (1) and (2), we obtain the following formula:

$\mathrm{H}_{2} \mathrm{O}_{2}+2 \mathrm{H}^{+}+2 \mathrm{e}^{-} \rightarrow 2 \mathrm{H}_{2} \mathrm{O}$

This means that the overall reaction at the PB/FTO electrode is simply $\mathrm{H}_{2} \mathrm{O}_{2}$ reduction in the acidic environment. To further understand the electrode kinetics, the sampledcurrent voltammogram for the stationary $\mathrm{H}_{2} \mathrm{O}_{2}$ reduction at the PB/FTO electrode (see Fig. 3) is re-plotted in Fig. 4. Fig. 4 presents the sampled-current voltammograms in the form of $E$ versus $\log \left[\left(I_{\mathrm{L}}-I\right) / I\right]$, where $E$ is the electrode potential, $I$ the sampling current, and $I_{\mathrm{L}}$ the limiting current. Fig. 4 is known as a wave-slope plot and can be fitted by the following equation in the case of totally irreversible kinetics:

$E=E_{1 / 2}+\frac{2.303 R T}{\alpha n F} \log \left[\frac{I_{\mathrm{L}}-I}{I}\right]$

where $E_{1 / 2}$ is the half-wave potential, $n$ the number of electrons transferred during the $\mathrm{H}_{2} \mathrm{O}_{2}$ reduction, $\alpha$ the transfer coefficient, $F$ the Faraday constant, and $R T$ remains its physical meaning. By fitting, we obtain

$E_{1 / 2}=122.4 \mathrm{mV}$

$$
\frac{2.303 R T}{\alpha n F}=154.5 \mathrm{mV}
$$

The half-wave potential estimated here is more negative by ca. $77 \mathrm{mV}$ when compared to the redox potential of the $\mathrm{PB} / \mathrm{PW}$ redox system in the absence of $\mathrm{H}_{2} \mathrm{O}_{2}$ (see Fig. 1). This verifies that the PB-to-PW reduction takes place ahead of the $\mathrm{H}_{2} \mathrm{O}_{2}$ reduction and is in accordance with Eq. (2). Meanwhile, the second fitting parameter describes that the

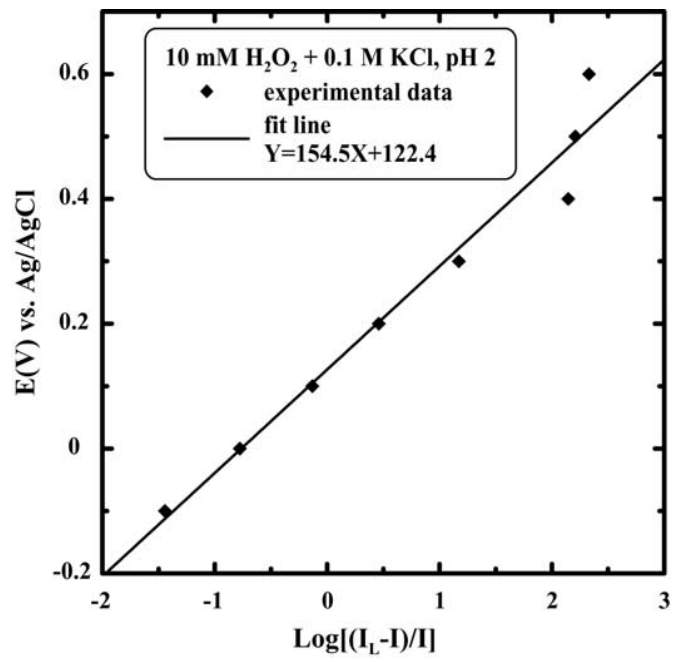

Fig. 4. The wave-slope plot presenting the stationary sampled-current voltammogram of Fig. 3 in the form of $E$ vs. $\log \left[\left(I_{\mathrm{L}}-I\right) / I\right]$, where $E$ is the electrode potential, $I$ the sampling current, and $I_{\mathrm{L}}$ the limiting current. transfer coefficient, $\alpha$, for the overall electrode process is equal to ca. 0.19 if two-electron-transfer reaction (3) takes place in one step at $25^{\circ} \mathrm{C}$. (The value of $F / R T$ is $38.92 \mathrm{~V}^{-1}$ at $25^{\circ} \mathrm{C}$.) But, the overall electrode process involves reactions (1) and (2). Therefore, the transfer coefficient estimated here might be less reliable.

\subsection{Amperometric detection of $\mathrm{H}_{2} \mathrm{O}_{2}$}

Fig. 5 demonstrates the successful $\mathrm{H}_{2} \mathrm{O}_{2}$ detection at the $\mathrm{PB} / \mathrm{FTO}$ electrode. The calibration curve, plotting steadystate currents versus $\mathrm{H}_{2} \mathrm{O}_{2}$ concentrations, is highly linear (ca. $R^{2}=0.9997$ ) and features a detection sensitivity of ca. $58.1 \mathrm{~mA} / \mathrm{cm}^{2} \mathrm{M}$. The highly linear correlation could be attributed to first-order chemical kinetics or linear diffusion. Experiments were performed with the same electrode and the numbers in Fig. 5 represent the detection sequence (we operated from $100 \mu \mathrm{M}$ to $20 \mathrm{mM}$ and then reversed the detection sequence). Obviously, detection sequence does not alter the calibration curve. Yet, the PB film was slightly degraded after 16-round detection by judging from the decrease of current response. To more precisely evaluate the run-to-run deviation of $\mathrm{H}_{2} \mathrm{O}_{2}$ response, a PB/FTO electrode was used to continuously detect $10 \mathrm{mM} \mathrm{H}_{2} \mathrm{O}_{2}$ (in the presence of $0.1 \mathrm{M}$ $\mathrm{KCl}, \mathrm{pH}$ 2) 40 times, and the results are presented in Fig. 6. (Before each run, the PB/FTO electrode was re-equilibrated at $0.70 \mathrm{~V}$ versus $\mathrm{Ag} / \mathrm{AgCl} /$ saturated $\mathrm{KCl}$ for $30 \mathrm{~s}$.) It reveals that the sensing current suffered from an early decay but then became steady after 10 runs of detection. When compared to the fresh PB film, $17 \%$ of charge capacity was lost after 40 runs of $\mathrm{H}_{2} \mathrm{O}_{2}$ sensing. On average, charge capacity loss was

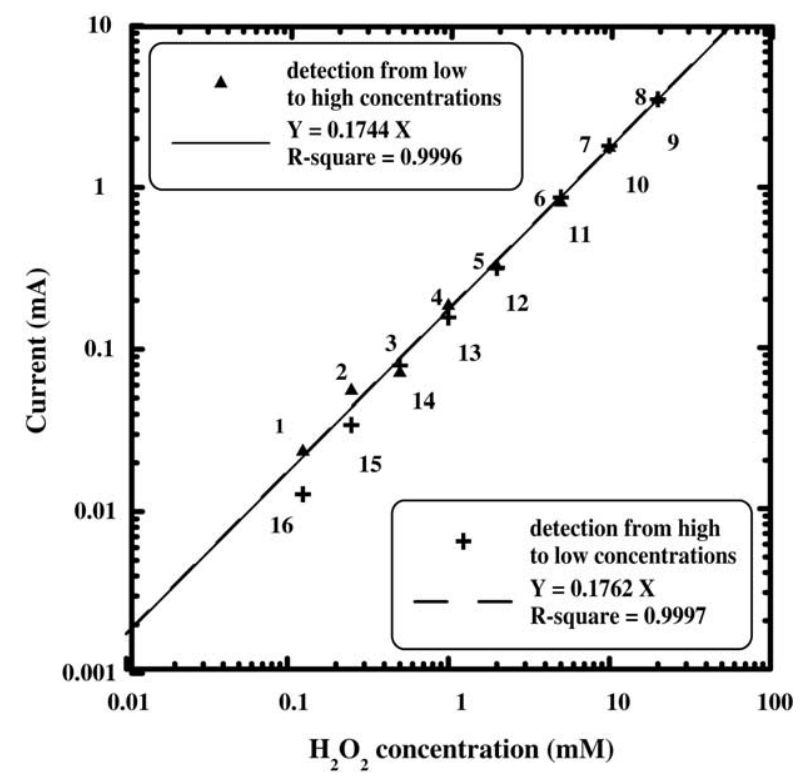

Fig. 5. Calibration curves demonstrating the $\mathrm{H}_{2} \mathrm{O}_{2}$ detection at the $\mathrm{PB} / \mathrm{FTO}$ electrode in the presence of $0.1 \mathrm{M} \mathrm{KCl}, \mathrm{pH} 2$. Numbers in the figure represent the sensing sequence. The sensing potential was $-0.20 \mathrm{~V}$ vs. $\mathrm{Ag} / \mathrm{AgCl} / \mathrm{saturated} \mathrm{KCl}$. Sampling time $=100 \mathrm{~s}$. Before each run, the $\mathrm{PB} / \mathrm{FTO}$ electrode was re-equilibrated at $0.70 \mathrm{~V}$ for $30 \mathrm{~s}$. 


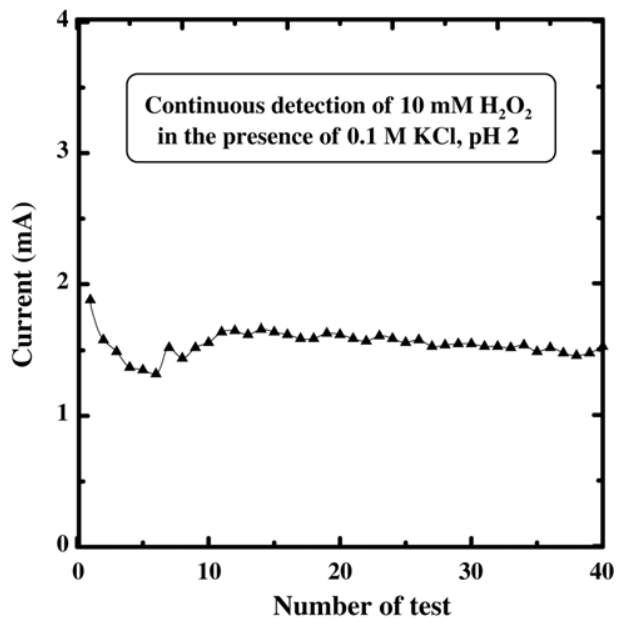

Fig. 6. Forty-round continuous detection of $10 \mathrm{mM} \mathrm{H}_{2} \mathrm{O}_{2}$ in the presence of $0.1 \mathrm{M} \mathrm{KCl}, \mathrm{pH}$ 2. Detection method is the same as that described in Fig. 5.

smaller than $0.5 \%$ per run. The degradation could be due to the decomposition of $\mathrm{PW}$ to $\mathrm{Fe}^{2+}$ and $\mathrm{Fe}(\mathrm{CN})_{6}{ }^{4-}$ ions, and it was reported that the stability of the PB-modified electrode could be improved by drying the PB films at $100^{\circ} \mathrm{C}$ for $1 \mathrm{~h}$ before using [21].

To evaluate the detection limits, a wide-range $\mathrm{H}_{2} \mathrm{O}_{2}$ detection (concentrations ranged from $1 \mu \mathrm{M}$ to $60 \mathrm{mM}$ ) was performed, and the results are plotted in Fig. 7. On the basis of the calibration curve in Fig. 7, the high and low detection limits are estimated to be $50 \mathrm{mM}$ and $50 \mu \mathrm{M}$, respectively. That is, when the concentration is out of the limits, the current response will be no longer proportional to the bulk concentration of $\mathrm{H}_{2} \mathrm{O}_{2}$ and becomes unreliable. Accordingly, the dynamic range (linear detection range) is almost across three orders. The high detection limit is presumably caused by the depletion of PW when catalyzing highly concentrated $\mathrm{H}_{2} \mathrm{O}_{2}$; nonetheless, sample dilution can resolve this kind of

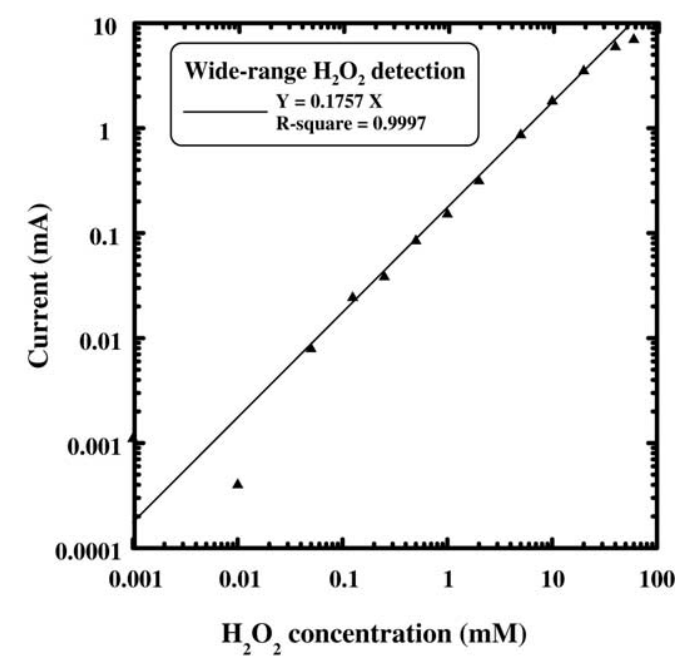

Fig. 7. A wide-range $\mathrm{H}_{2} \mathrm{O}_{2}$ detection (concentrations ranged from $1 \mu \mathrm{M}$ to $60 \mathrm{mM}$ ) for estimation of detection limits. Detection method is the same as that described in Fig. 5. problem. Thus, the practical sensing issue is to lower the detection limit. In the present case, the limitation on the low detection limit might be attributed to the interference of dissolved oxygen, which oxidized PW to PB and then led to a background signal. Besides, this could be an intrinsic issue for the static, macro-electrode system. Table 1 clearly shows that not only higher sensitivity but wider dynamic range could be obtained in convective, stirred systems, as compared to those of static detections. Especially, it was reported recently that a nano-structured PB-modified electrode coupled with the flow injection system could effectively boost the dynamic range of $\mathrm{H}_{2} \mathrm{O}_{2}$ detection to six orders $\left(10^{-8}\right.$ to $\left.10^{-2} \mathrm{M}\right)$ [17]. Hence, proper convective source, electrode miniaturization, and analyte enrichment can be useful strategies for improving the present system's detection limits.

\subsection{Effects of the dissolved oxygen}

It was reported that the dissolved oxygen in the bulk solution would be reduced to water when the potential of a PB-modified electrode was lower than $0.2 \mathrm{~V}$ (versus SCE) [20]. This implies that the dissolved oxygen and $\mathrm{H}_{2} \mathrm{O}_{2}$ are competing for the reductive electrons transferred from the PW. Therefore, the $\mathrm{H}_{2} \mathrm{O}_{2}$ detection interferes with the dissolved oxygen if the analyte concentration is relatively low. To illustrate how the dissolved oxygen affects the $\mathrm{H}_{2} \mathrm{O}_{2}$ sensing, Fig. 8 compares the low-concentration calibration curves $(0-0.25 \mathrm{mM})$ obtained before and after $5 \mathrm{~min} \mathrm{~N}_{2}$ purging to investigate how the dissolved oxygen from the ambient affects the $\mathrm{H}_{2} \mathrm{O}_{2}$ detection. It is obvious that sensing currents obtained without $\mathrm{N}_{2}$ purging are slightly higher than those obtained with $\mathrm{N}_{2}$ purging. The data support that the dissolved oxygen from the ambient atmosphere contributes additive

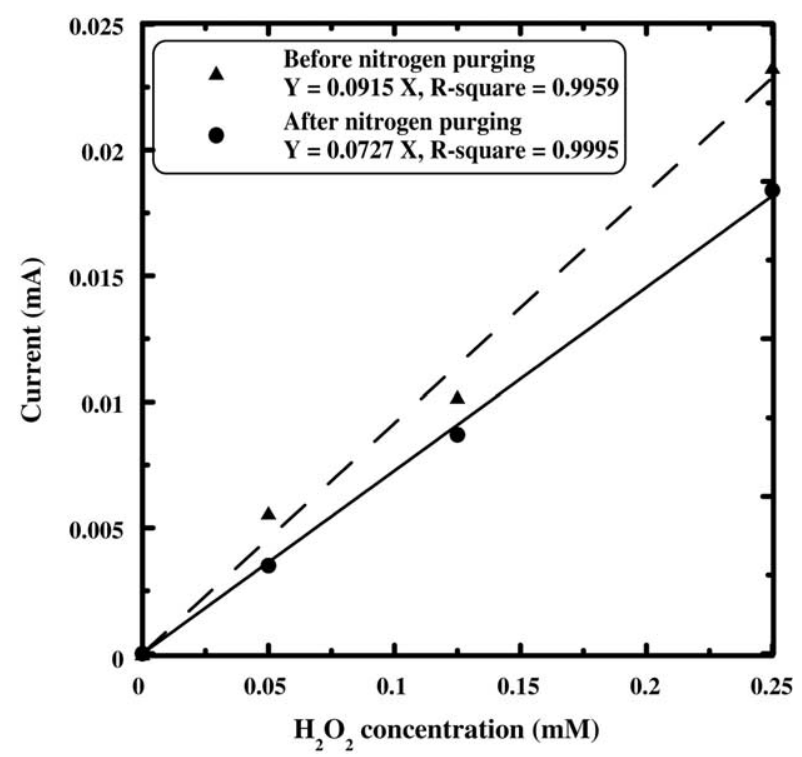

Fig. 8. The interference of dissolved oxygen. The calibration curves of $\mathrm{H}_{2} \mathrm{O}_{2}$ detection before and after $5 \mathrm{~min} \mathrm{~N}_{2}$ purging are compared. Detection method is the same as that described in Fig. 5. 
current responses for the amperometric $\mathrm{H}_{2} \mathrm{O}_{2}$ detection. On the other hand, the $\mathrm{N}_{2}$-purged current is more linearly dependent on the $\mathrm{H}_{2} \mathrm{O}_{2}$ concentration $\left(R^{2}=0.9995\right)$ than that without $\mathrm{N}_{2}$ purging $\left(R^{2}=0.9959\right)$. So we infer that removal of dissolved oxygen might widen the dynamic range of the $\mathrm{H}_{2} \mathrm{O}_{2}$ detection. However, as far as some biosensor applications are concerned, the presence of oxygen is necessary. For example, a PB-based glucose sensor [10] is known to function based on the following principle:

Glucose $+\mathrm{O}_{2} \stackrel{\text { GOD }}{\longrightarrow}$ Gluconic acid $+\mathrm{H}_{2} \mathrm{O}_{2}$

And it is the dissolved oxygen that reacts with glucose and glucose oxidase (GOD) to yield $\mathrm{H}_{2} \mathrm{O}_{2}$ for PB-mediated amperometric detection. Thus, one should consider if the $\mathrm{N}_{2}$ purging is appropriate treatment before performing $\mathrm{H}_{2} \mathrm{O}_{2}$ sensing.

\section{Conclusions}

On the basis of the above results and discussions, a reliable and reproducible amperometric detection of $\mathrm{H}_{2} \mathrm{O}_{2}$ at the PB/FTO electrode has been verified. In conclusions, we summarize the major findings of this work as follows:

1. $\mathrm{H}_{2} \mathrm{O}_{2}$ catalytic reduction occurs after the formation of $\mathrm{PW}$ and requires low-pH environment, for example, $\mathrm{pH}$ 2. Besides, the existence of $\mathrm{K}^{+}$ions $(0.1 \mathrm{M} \mathrm{KCl})$ effectively reduces the catalytic overpotential and enlarges the catalytic current.

2. Reliable and reproducible amperometric detection can be achieved by applying a constant potential of $-0.20 \mathrm{~V}$ (versus $\mathrm{Ag} / \mathrm{AgCl} /$ saturated $\mathrm{KCl}$ ) at the $\mathrm{PB} / \mathrm{FTO}$ electrode in contact with a stationary $\mathrm{H}_{2} \mathrm{O}_{2}$ solution in the presence of $0.1 \mathrm{M} \mathrm{KCl}, \mathrm{pH} 2$.

3. The detection current responds to the bulk solution of $\mathrm{H}_{2} \mathrm{O}_{2}$ linearly when the concentration ranges between $50 \mu \mathrm{M}$ and $50 \mathrm{mM}$. The sensitivity within this dynamic range is estimated to be ca. $58.1 \mathrm{~mA} / \mathrm{cm}^{2} \mathrm{M}$.

4. Dissolved oxygen is to affect the reductive $\mathrm{H}_{2} \mathrm{O}_{2}$ detection at the $\mathrm{PB} / \mathrm{FTO}$ electrode and to contribute additive current responses. $\mathrm{N}_{2}$ purging can minimize the interference of dissolved oxygen.

In addition to the above findings, we believe that this work also provides the opportunities for reducing the cost of a PB-based sensor and helps for the design of optical sensing devices.

\section{Acknowledgement}

The financial support, provided by the Ministry of Education of ROC through the Program for Promoting Academic Excellence of University, under grant number EX91E-F-FA09-5-4, is acknowledged.

\section{References}

[1] P. Westbroek, E. Temmerman, P. Kiekens, Measurement and control of hydrogen peroxide concentration in alkaline solution by means of amperometric sensor system, Anal. Chim. Acta 385 (1999) 423428 .

[2] L. Campanella, R. Roversi, M.P. Sammartino, M. Tomassetti, Hydrogen peroxide determination in pharmaceutical formulations and cosmetics using a new catalase biosensor, J. Pharm. Biomed. Anal. 18 (1998) 105-116.

[3] T.M. Schreirer, J.J. Rach, G.E. Howe, Efficacy of formalin, hydrogen peroxide, and sodium chloride on fungal-infected rainbow trout eggs, Aquaculture 140 (1996) 323-331.

[4] T. Ruzgas, E. Csöregi, J. Emnèus, L. Gorton, G. Marko-Varga, Peroxidase-modified electrodes: fundamentals and application, Anal. Chim. Acta 330 (1996) 123-138.

[5] G.G. Guilbault, G.J. Lubrano, D.N. Gray, Glass-metal composite electrodes, Anal. Chem. 45 (1973) 2255-2258.

[6] G.G. Guilbault, G.J. Lubrano, Amperometric enzyme electrodes: Part II. Amino acid oxidase, Anal. Chim. Acta 69 (1974) 183188

[7] J.A. Cox, R.K. Jaworski, Voltammetric reduction and determination of hydrogen peroxide at an electrode modified with a film containing palladium and iridium, Anal. Chem. 61 (1989) 2176-2178.

[8] Z. Taha, J. Wang, Electroanalysis and flow detection at a glassy carbon electrode modified with a thin film of oxymanganese species, Electroanalysis 3 (1991) 215.

[9] S.B. Khoo, M.G.S. Yap, Y.L. Huang, S. Guo, Electrocatalytic oxidation of $\mathrm{H}_{2} \mathrm{O}_{2}$ at an oxycobalt film modified glassy carbon electrode for fermentation monitoring, Anal. Chim. Acta 351 (1997) 133142.

[10] A.A. Karyakin, O.V. Gitelmacher, E.E. Karyakina, Prussian Bluebased first-generation biosensor: a sensitive amperometric electrode for glucose, Anal. Chem. 67 (1995) 2419-2423.

[11] A.A. Karyakin, E.E. Karyakina, Prussian Blue-based 'artificial peroxidase' as a transducer for hydrogen peroxide detection: application to biosensors, Sens. Actuators B: Chem. 57 (1999) 268-273.

[12] M.S. Lin, T.F. Tseng, W.C. Shih, Chromium(III) hexacyanoferrate(II)-based chemical sensor for the cathodic determination of hydrogen peroxide, Analyst 123 (1998) 159-166.

[13] M.P. O’Halloran, M. Pravda, G.G. Guilbault, Prussian Blue bulk modified screen-printed electrodes for $\mathrm{H}_{2} \mathrm{O}_{2}$ detection and for biosensors, Talanta 55 (2001) 605-611.

[14] S.A. Jaffari, A.P.F. Turner, Novel hexacyanoferrate(III) modified graphite disc electrodes and their application in enzyme electrodes-Part I, Biosens. Bioelectron. 12 (1997) 1-9.

[15] R. Garjonyte, A. Malinauskas, Electrocatalytic reactions of hydrogen peroxide at carbon paste electrodes modified by some metal hexacyanoferrates, Sens. Actuators, B: Chem. 46 (1998) 236-241.

[16] I.L. Mattors, L. Gorton, T. Ruzgas, A.A. Karyakin, Sensor for hydrogen peroxide based on Prussian Blue modified electrode: improvement of the operational stability, Anal. Sci. 16 (2000) 795-798.

[17] A.A. Karyakin, E.A. Puganova, I.A. Budashov, I.N. Kurochkin, E.E. Karyakina, V.A. Levchenko, V.N. Matveyenko, S.D. Varfolomeyev, Prussian Blue based nanoelectrode arrays for $\mathrm{H}_{2} \mathrm{O}_{2}$ detection, Anal. Chem. 76 (2004) 474-478.

[18] V.D. Neff, Electrochemical oxidation and reduction of thick films of Prussian Blue, J. Electrochem. Soc. 125 (1978) 886.

[19] K. Itaya, I. Uchida, V.D. Neff, Electrochemistry of polynuclear transition metal cyanides: Prussian Blue and its analogues, Acc. Chem. Res. 19 (1986) 162-168.

[20] K. Itaya, N. Shoji, I. Uchida, Catalysis of the reduction of molecular oxygen to water at Prussian Blue modified electrodes, J. Am. Chem. Soc. 106 (1984) 3423-3429.

[21] A.A. Karyakin, E.E. Karyakina, L. Gorton, On the mechanism of $\mathrm{H}_{2} \mathrm{O}_{2}$ reduction at Prussian Blue modified electrodes, Electrochem. Commun. 1 (1999) 78-82. 
[22] R. Garjonyte, A. Malinauskas, Operational stability of amperometric hydrogen peroxide sensors, based on ferrous and copper hexacyanoferrates, Sens. Actuators, B: Chem. 56 (1999) 93-97.

[23] R. Garjonyte, A. Malinauskas, Glucose biosensor based on glucose oxidase immobilized in electropolymerized polypyrrole and poly( $o$-phenylenediamine) films on a Prussian Blue-modified electrode, Sens. Actuators, B: Chem. 63 (2000) 122-128.

[24] K.C. Ho, C.L. Lin, A novel potassium ion sensing based on Prussian Blue thin films, Sens. Actuators, B: Chem. 76 (2001) 512-518.

[25] K. Itaya, T. Ataka, S. Toshima, Spectroelectrochemistry and electrochemical preparation method of Prussian Blue modified electrodes, J. Am. Chem. Soc. 104 (1982) 4767-4772.

\section{Biographies}

Kuei-Sheng Tseng received his BS degree in chemical engineering from National Taiwan University, Taipei, Taiwan in 2000. He received MS degree in chemical engineering from National Taiwan University in 2002. Currently, he is a research and development engineer at AU Optronics Corporation, Hsinchu Science Park, Taiwan. His research interest mainly is in the electrochemical sensor applications using chemically modified electrodes.
Lin-Chi Chen received his BS degree in chemical engineering from National Taiwan University, Taipei, Taiwan in 1997. He received $\mathrm{PhD}$ degree in chemical engineering from National Taiwan University in 2001. Currently he is a postdoctoral research fellow in the Institute of Biomedical Sciences at Academia Sinica, Taipei, Taiwan. His research interest includes antibody mimics, microarray technology, and integrated electrochemical systems.

Kuo-Chuan Ho received BS and MS degrees in chemical engineering from National Cheng Kung University, Tainan, Taiwan, in 1978 and 1980, respectively. In 1986, he received the $\mathrm{PhD}$ degree in chemical engineering at the University of Rochester. The same year he joined PPG Industries Inc., first as a senior research engineer and then, from 1990 until 1993, as a research project engineer. He has worked on the electrochemical properties of various electrode materials, with emphasis on improving the performances of sensor devices. Following a 6-year industrial career at PPG Industries Inc., he joined his alma mater at National Cheng Kung University in 1993 as an Associate Professor in the Chemical Engineering Department. In 1994, he moved to the Department of Chemical Engineering at National Taiwan University. Currently, he is a Professor jointly appointed by the Department of Chemical Engineering and Institute of Polymer Science and Engineering at National Taiwan University. 